\title{
Employee Job Satisfaction and Organizational Performance on the National Shipping Company
}

\author{
Prasadja Ricardianto $^{1, a}$, Weli Agus Setiawan ${ }^{2, b}, \operatorname{Veronica}^{3, c}$, Imam Sonny $^{4, d}$, \\ Esti Liana $^{5, e}$ \\ ${ }^{1,2,4}$ Transportation Management, Postgraduate Directorate, Trisakti Institute of Transportation and Logistics, \\ Jakarta, Indonesia \\ ${ }^{3}$ Faculty of Transportation and Logistics, Trisakti Institute of Transportation and Logistics, Jakarta, Indonesia \\ ${ }^{5}$ Faculty of Management and Business, Trisakti Institute of Transportation and Logistics, Jakarta, Indonesia \\ ${ }^{\mathrm{a}, \mathrm{b}}$ Weli Agus Setiawan, ${ }^{\mathrm{c}}$ veronicaparhusip2@gmail.com, dimam.sonny@dephub.go.id, esti_liana@yahoo.com
}

Corresponding Author: Prasadja Ricardianto

\begin{abstract}
This study aims to determine and analyze the contribution of transformational leadership styles and organization policy on employee job satisfaction which has implications for organizational performance in the Athamara Group. Some of the problems on Athamara Group as one of the national shipping company in Indonesia, namely, the level of employee job satisfaction and organizational performance is still low. The research sampling technique used a saturated sample of 102 people. Descriptive statistical analysis and path analysis were used as the analysis method. The results of this study are from seven proposed hypotheses, six of which are accepted and one of the hypotheses have no significant effect on organizational performance. The indirect contribution of transformational leadership style to organizational performance is through employee job satisfaction, although employee job satisfaction has no significant contribution on organizational performance. Finally, organizational policy has an indirect contribution on organizational performance through employee job satisfaction. The indirect contribution of organizational policy to organizational performance is through employee job satisfaction, although employee job satisfaction has no significant contribution on organizational performance. The key funding, that transformational leaders will convey organizational policy properly and appropriately, so that they are easily understood and implemented by employees.
\end{abstract}

Keywords: Employee Job Satisfaction; Organization Performance, Organizational Policy; Transformational Leadership Style; National Shipping Company

\section{INTRODUCTION}

Maximizing employees by providing motivation and encouragement to employees or followers about leadership, how should superiors be able to implement a leadership style that can motivate and inspire the employees to work as effectively and as efficiently possible in order to reach the company's objectives and improve organizational performance. Bosses who have a transformational leadership style can make employees more satisfied with the work they have. Organizational policy without socialization will make work uncomfortable for an employee, many factors influence an organization to make new policy, such as currently emerging global problems, namely the outbreak of the Covid-19 which almost all countries in the world feel the impact of this pandemic. In addition to threatening human life, this epidemic also has an impact on the macroeconomic sector. As a result, the agency/organization will issue new policy related to these problems, one of which is the agency/organization will lay off employees, employees will do office work at home, or even lay off employees. In this 
condition, an organizational leader must use a transformational leadership style that understands the current situation so that organizational policy can be accepted and implemented by employees properly. Some of the problems with Athamara Group as one of the national shipping businesses in Indonesia, namely, the level of employee job satisfaction is still low, and organizational performance is still low, such as improving the quality of human resources. Also, lack of transformational leadership style of the leader and as well as the level of employee loyalty is still low.

Based on the theory, according to (Gibson et al. 2012) that the organization can be understood as a coordinated unit, consisting of two or more people who function to achieve a common goal or set of goals. Organizational performance is a major construct in management research. According to (Bernadin and Russel 2005) understand performance as writing the achievements obtained from the use of work or special activities over a certain period. It can be determined that in terms of organizational performance of is the level of achievement obtained from the use of work or special activities by a company, both financial and non-financial. Based on previous research by (Shahzad et al. 2012), managers and leaders are advised to develop a strong culture within the organization to improve the performance of employees and the organization as a whole. Implementation of policies on shipping safety, such as paying attention to the equipment and safety equipment that must be provided, the seaworthiness of the ship, good navigation, every ship that sails is under the supervision of the shipping administration (Andry 2014; Suwestian, Ghalib, and Utomo 2015; Kadarisman 2017). Organizational performance is the dependent variable, which is created from three dimensions, namely: customer service quality, product quality, and company performance.

$$
\text { Based on the theory, }
$$
transformational leadership style is the ability to bring about significant changes to followers (Daft 2015; Newstrom 2015). Therefore, it could be said that a leader with transformational leadership style who has the power to effect by inspiring individuals or groups to work optimally while subordinate their personal ambitions to the ultimate goals of the organization. Previous study by (A. Mehrad and Fallahi 2014) states that inappropriate leadership style is a problem for every public educational organization. Leaders, who that supports employees, must be able to solve problems appropriately, and then direct employees to think and act creatively (Elgelal and Noermijati 2015). Transformational leadership style as true leadership, where superiors encourage their employees to work optimally to achieve the company's goals and which inspire and innovate the company (Italiani 2013).Transformational leadership behavior describes outcomes that reflect leader effectiveness, controlling for transactional leadership effects (Shin and Zhou 2003; Gong, Huang, and Farh 2009). Transformational leadership model for crew members who can build employee job satisfaction should pay more attention internal and external imbalances experienced by employees (Thamrin 2012). Through research by (Vasilcovschi and Georgescu 2012), can find out how the competitiveness of the global economy in the shipping industry is influenced by transformational leadership. According to (Tschannen-Moran 2003), explains that the characteristics of the transformational leadership style, which is a dependent variable consists of four dimensions, namely; 1) Idealized Influence; 2) Inspirational, Motivation; 3) Intellectual Stimulation; and 4) Individual Considerations.

Research on company policy, many shipping companies are adopting green shipping practices that emphasize environmental management throughout their operations (Lai et al. 2013). Several shipping company policies related to sailing safety have been previously researched by (Andry 2014; Suwestian, Ghalib, and 
Utomo 2015). According to (Jung and Kim 2012), that the competitive advantage of shipping companies is determined by their ability to provide integrated services. One of the shipping industry policies is to evaluate the company's ability to carry out reforestation operations, namely the company's business routines or activities, and the other concerns the company's ability to convert inputs into outputs (Lun et al. 2014). Organizational policy, which is a dependent variable, consists of three dimensions, namely; the ability to deliver policies, the ability to accept policies, and the organizational responsibility for the welfare of employees.

Based on the theory, job satisfaction as an emotional response to various aspects of one's work. This definition states that job satisfaction is not a single concept, and a person may be relatively satisfied with one aspect of his job (Kreitner and Kinicki 2011). According to (Robbins and Judge 2018), a transformational leadership style is a boss who inspires his employees to put aside their personal needs for the good of the organization and they can have a tremendous impact on their employees. According to (Pang and $\mathrm{Lu} 2018$ ), an empirical study of container shipping companies in Taiwan there are five dimensions of job satisfaction, namely: job policy, job autonomy, workload, work performance and job status. Meanwhile, research by (Jiang, Lu, and $\mathrm{Lu}$ 2017) in Shanghai Port shows more job dissatisfaction when some container workers experience conditions such as more working hours, lower income, expensive diesel fuel. Employee job satisfaction, as an intervening variable, is formed from five dimensions, namely: satisfaction with salary, promotion, co-workers, leadership and own work.

Whereas, the main study aims to determine and analyze the effect of transformational leadership styles and organization policy on employee job satisfaction which has implications for organizational performance in the Athamara Group as a national Ships. Several other objectives operationally are, want to know and analyze directly employee job satisfaction has a significant effect on organizational performance. Indirectly, also want to know and analyze leadership style that has a significant effect on organizational performance and to know and indirectly analyze organizational policies that have a significant effect on organizational performance in Athamara Group as a national private shipping company in Indonesia.

\section{Hypotheses}

H1: Transformational leadership style positively contributes to the employee job satisfaction

$\mathrm{H} 2$ : Organizational policy positively contributes on the employee job satisfaction

H3: Transformational Leadership style positively contributes on the performance of organizational

H4: Organizational policy positively contributes on the performance of organizational

H5: Employee job satisfaction positively contributes on the performance of organizational

H6: Transformational leadership style positively contributes on the performance of organizational

H7: Organizational policy positively contributes on the performance of organizational

This study examines the contribution of transformational leadership style (X1) and organizational policy (X2) as independent variables, on employee job satisfaction (Y) as an intervening variable, and its implications for organizational performance $(\mathrm{Z})$ as the dependent variable (Figure 1). 


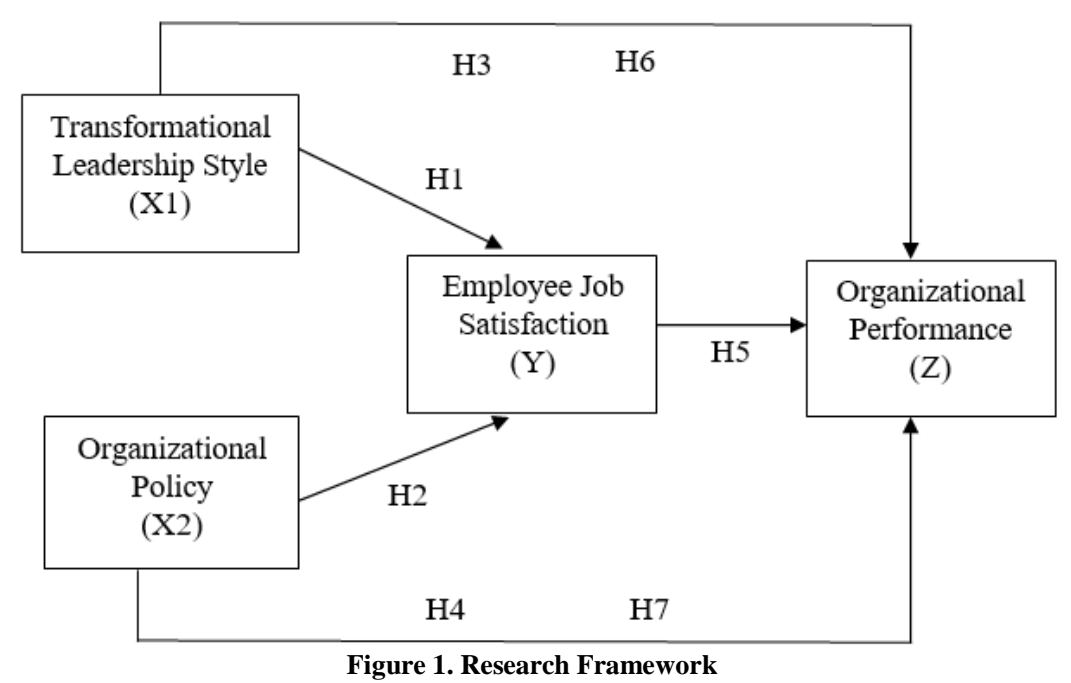

\section{RESEARCH METHODS \\ Population, Sample and Data \\ Determination Technique}

The data collection method in this study was done by making direct observations or field observations. In addition, this study also conducted semistructured interviews directly with informants or resource persons. Furthermore, the distribution of questionnaires is one of the data collection methods that was done by issuing or handing out a series of questions to respondents. In this study, the tools used are in the form of a questionnaire, namely a questionnaire on employee empowerment strategy management, employee core competencies, employee performance, and the quality of port services. The research sampling technique used a saturated sample of 102 people.

\section{Analysis Techniques in Partial Least Square Method}

This study uses a quantitative approach to verification research and data collection techniques using questionnaires. Descriptive statistical analysis and path analysis were used as the analysis method. Researchers use path analysis due to examine causal correlations, to describe the direct or indirect effects between exogenous and endogenous variables. To test the hypothesis and create a fit model, Path Analysis is used in this study, namely to test the impact of leadership style, organizational policy, and employee job satisfaction on organizational performance by linking the intervening variables of employee job satisfaction. Path Analysis is an extension of multiple linear regression analysis, where regression analysis was used to approximate any causality correlations between variables.

\section{RESULTS AND DISCUSSION \\ Hypotheses Testing}

Testing The Influence Hypothesis Direct Leadership Style (X1) on Employee Job Satisfaction (Y)

Based on the calculation results, the number ttable $=1.984$, when compared with the value of tstatistics $=4.211$ then tstatistics > ttable $(4.211>1984)$, therefore, Hyphoteses 1 is acceptable. This indicates that there exists a direct effect of leadership style (X1) on employee job satisfaction (Y). The direct contribution of leadership style (X1) to employee job satisfaction (Y) is $15.054 \%$.

\section{Testing The Influence Hypothesis Directly Organizational Policy (X2) on Employee Job Satisfaction (Y)}

Based on the calculation results, the number ttable $=1.984$. when compared with the value of tstatistics $=6,576$ then tstatistics > ttable $(6,576>1984)$, therefore, Hyphoteses 1 is acceptable. This indicate that there exists a direct effect of 
organizational policy (X2) on employee job satisfaction (Y). The direct contribution of organizational policy (X2) to employee job satisfaction $(\mathrm{Y})$ is $30.14 \%$.

Testing The Influence Hypothesis Direct Leadership Style (X1) on Organizational Performance (Z)

Based on the calculation results, the number ttable $=1.984$. when compared with the value of tstatistics $=3,212$ then tstatistics $>$ ttable $(3,212>1984)$, Hyphoteses 1 is acceptable. This indicate that there exists a direct effect of leadership style (X1) on organizational performance $(\mathrm{Z})$. The direct contribution of leadership style (X1) on organizational performance $(\mathrm{Z})$ is $9.364 \%$.

\section{Testing The Influence Hypothesis Directly Organizational Policy (X2) on Organizational Performance $(\mathbf{Z})$}

Based on the calculation results, the value of ttable $=1.984$. when compared with the value of tstatistics $=5,823$ then tstatistics > ttable $(5,823 \quad>1984)$, Hyphoteses 1 is acceptable. This indicates that there exists a direct effect of organizational policy (X2) on organizational performance $(Z)$. The direct contribution of organizational policy (X2) to organizational performance $(\mathrm{Z})$ is $25.30 \%$.

Testing The Influence Hypothesis Directly Employee Job Satisfaction (Y) on Organizational Performance $(Z)$

Based on the calculation results, the value ttable $=1.984$. when compared with the value of tstatistics $=10,713$ then tstatistics > ttable $(10,713>1984)$, Hyphoteses 1 is acceptable. This indicate that there exists a direct effect of employee job satisfaction (Y) on organizational performance $(\mathrm{Z})$. The direct contribution of employee job satisfaction (Y) to organizational performance $(\mathrm{Z})$ is $53.436 \%$.

Test Hypothesis of Indirect Influence of Leadership Style (X1) on Organizational Performance (Z) Through Employee Job Satisfaction (Y)

Based on the results of path analysis, the path coefficient value of transformational leadership style (X1) on organizational performance (Z) through employee job satisfaction $(\mathrm{Y})$ is obtained. The value is obtained $\rho_{X 1 Y Z}<\rho_{Z X 1}(0.284<$ 0.360). In that regard, interpreting the intervening variable has no significant effect on organizational performance.

Test The Hypothesis Indirect Influence Organizational Policy (X2) on Organizational Performance (Z) Through Employee Job Satisfaction (Y)

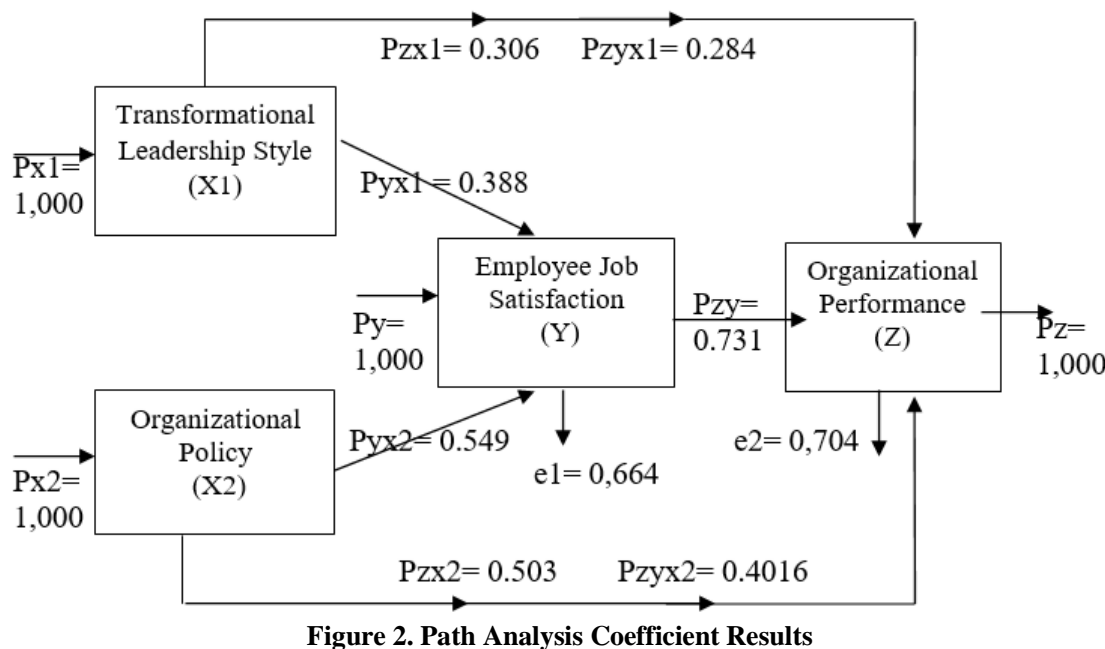

Based on the achievement of path analysis, the path coefficient number of organizational policy variables (X2) on organizational performance (Z) through 
employee job satisfaction (Y) is obtained. Employee (Y) $\rho_{X 2 Y Z}=\rho_{Y X 2} x \rho_{Z Y}=0.4016$. when compared to the value of $\rho_{Z X 2}=0.503$. then the value is obtained $\rho_{X 2 Y Z}<\rho_{Z X 2}(0.4016<0.503)$. About that interpreting the intervening variable no significant effect on organizational performance.

Based on the above calculations, the following figures are obtained: The path coefficient number can then be entered into the path analysis model as follows (Figure 2).

\section{DISCUSSION}

\section{Transformational Leadership Style and Employee Job Satisfaction}

Based on the above analysis, it could be concluded that transformational leadership style has a direct effect on employee job satisfaction. The direct contribution of transformational leadership style to employee job satisfaction is $15.054 \%$. Such analysis outcome strengthens the results of previous studies implemented by (Mancheno-Smoak et al. 2009) the influence of transformational leadership is also caused by work-related cultural values and job satisfaction variables. Other factors mentioned in the study include involvement of crew members and the work-life balance. The study elaborated further that such direct effects could be perceived through several dimensions, which are: work reliability dimension from the effectiveness of crew members, intellectual stimulation from the leadership style, the work-life balance, and the loyalty dimension from the engaged and committed workers. Further studies carried out by (Mujkić et al. 2014; Riana, Sintaasih, and Suprapta 2015), concluded that leadership style affect job satisfaction. In addition, also the results of the another analysis are strengthened by (Pratama 2016; Muslichah and Asrori 2018) indicate that transformational leadership has a positive and significant impact on job satisfaction. The results of the research in China show that there is a significant positive effect on leadership style on job satisfaction and it is hoped that seafarers will survive the human resource gap and become a reference for human resource management in the domestic shipping industry (Yao and Huang 2018).

Therefore, the findings of this study support previous research and theories. This means that transformational leadership style has a direct effect on employee job satisfaction.

\section{Organizational Policy and Employee Job Satisfaction}

Next, organizational policy also has a direct effect on employee job satisfaction. The direct contribution of organizational policy to employee job satisfaction is $30.14 \%$. The results of the analysis are by statement (Babalola 2016) study achievements which concluded that job satisfaction, relationship between supervisor and supervisee, as well as hands-off and trusting leadership style were shown to significantly affect organizational commitment. Next, (Elgelal and Noermijati 2015) stated that Intellectual Stimulation is the major barometer in the measurement of transformational leadership, where employees are expected and encouraged by their leaders to act creatively and to be able to solve problems accurately and attentively. In adition, result of study in the Terminal Operation Context of Kaohsiung Port at Taiwan states that employee job satisfaction is closely related to organizational climate (Tsai 2014).

Therefore, the findings of this study support previous research and theories. This means that organizational policy also has a direct effect on employee job satisfaction.

\section{Transformational Leadership Style and Organizational Performance}

Transformational leadership style has a direct effect on organizational performance. The direct contribution of leadership style on organizational performance is $9.364 \%$. This is in accordance with the finding from the study done by Mehrad \& Fallahi (2014) which discussed about the appropriate 
leadership style for public educational organization. Their study found that employee dissatisfaction towards their leaders could significantly lower their overall performance. Another example is on leadership development impacting organizational performance on research aboard United States Navy ship (Hase 2007). Another study, transformational leadership effect on organizational innovation and organizational performance of manufacturing companies (Noruzy et al. 2013). However, this is in contrast to the study done by Noviyanti et al. (2019) where one of the results showed that direct leadership style has no significant effect on employee performance.

Therefore, the findings of this study support previous research and theories. This means that transformational leadership style has a direct effect on organizational performance.

\section{Organizational Policy and Organizational Performance}

Organizational policy has a direct effect on organizational performance. The direct contribution of organizational policy to organizational performance is $25.30 \%$. This study support the findings (Alkalha et al. 2012), that show strong support for the model, which indicates that human resource policy are positively related to organizational performance and have a strong statistical significance.

Therefore, the findings of this study support previous research and theories. This means that organizational policy has a direct effect on organizational performance.

\section{Employee Job Satisfaction and Organizational Performance}

Employee job satisfaction also has a direct effect on organizational performance. The direct contribution of employee job satisfaction to organizational performance is $53.436 \%$. The results of a study in Croatia by (Bakotić 2016), showed a clear relationship between employee job satisfaction and organizational performance.
Another understanding is that job satisfaction affects organizational performance, not organizational performance that affect job satisfaction. In addition, (Latif et al. 2013; Purnama 2013) stated that employee job satisfaction also has a direct effect on organizational performance. Based on the research findings as a whole it can be said that there is a strong positive relationship between employee job satisfaction and organizational performance (Miah 2018).

Therefore, the findings of this study support previous research and theories. This means that employee job satisfaction also has a direct effect on organizational performance.

\section{Transformational Leadership Style, Organizational Performance and Employee Job Satisfaction}

Transformational leadership style has an indirect effect on organizational performance through employee job satisfaction. Indirect contribution of leadership style on organizational performance through employee job satisfaction, although intervention variables (employee job satisfaction) have no significant effect on organizational performance. The magnitude of the indirect effect is $8.066 \%$. Therefore, (Amarjit, Flaschner, and Smita 2010) conducting research that shows that there exists affect between transformational leadership with job satisfaction, organizational leaders are advised to take action and role as transformational leaders because this leadership is proven to bring good change. Although the relationship between transformational leadership and organizational performance is similar in the two models, in the follower perception model the effect is almost entirely mediated by employee job satisfaction (Muterera et al. 2018).

Therefore, the findings of this study support previous research and theories $s$. This means that transformational leadership style has an indirect effect on organizational 
performance through employee job satisfaction.

\section{Organizational Policy, Organizational Performance and Employee Job Satisfaction}

Organizational policy has an indirect effect on organizational performance through employee job satisfaction. The indirect contribution of organizational policy to organizational performance through employee job satisfaction, although intervention variables (employee job satisfaction) have no significant effect on organizational performance. The magnitude of the indirect effect is $16.128 \%$. According to research (Chandrasekara 2019) researching with study achievements showing transformational leadership significantly and positively affect job satisfaction and performance.

Therefore, the findings of this study support previous research and theories. This means that organizational policy has an indirect effect on organizational performance through employee job satisfaction.

\section{CONCLUSION}

Job satisfaction factors mediate the effect of transformational leadership style on organizational performance. This satisfaction is what drives employees to work better. Organizational policy factors on organizational performance, in this study, do not directly affect organizational performance, but through job satisfaction. Transformational leaders will convey organizational policy properly and appropriately, so that they are easily understood and implemented by employees. Employees who understand their duties and obligations, enjoy their profession and can see opportunities to develop themselves, will feel satisfied in their work. Job satisfaction is what drives employees to work well. The findings of this study establish the need for further studies using certain methods on transformational leadership style and organizational policy through mediation of employee job satisfaction as factors that can improve organizational Performance in national shipping companies in Indonesia.

\section{Acknowledgement: None}

\section{Conflict of Interest: None}

\section{Source of Funding: None}

\section{REFERENCES}

1. Alkalha, Z., Z. Al-Zu'bi, H. Al-Dmour, M. Alshurideh, and R. Masa'deh. 2012. "Investigating the Effects of Human Resource Policies on Organizational Performance: An Empirical Study on Commercial Banks Operating in Jordan." European Journal of Economics, Finance and Administrative Sciences 51 (1): 44-64.

2. Amarjit, G., A. B. Flaschner, and B. Smita. 2010. "The Impact of Transformational Leadership and Empowerment on Employee Job Stress." Business and Economics Journal 1 (1). https://doi.org/10.4172/21516219.1000003.

3. Andry, F. Y. 2014. "Implementation of Shipping Safety Policy Kebijakan.” Jurnal Administrasi Pembangunan 2 (3): 259-264.

4. Babalola, S. S. 2016. "The Effect of Leadership Style, Job Satisfaction and Employee-Supervisor Relationship on Job Performance and Organizational Commitment." Journal of Applied Business Research $32 \quad$ (3): $\quad 935-46$. https://doi.org/10.19030/jabr.v32i3.9667.

5. Bakotić. 2016. "Relationship between Job Satisfaction and Organisational Performance." Ekonomska Istraživanja 29 (1): 118-130. https://doi.org/https://doi.org/ 10.1080/1331677X.2016.1163946.

6. Bernadin, H. J., and E.A. Russel. 2005. Human Resources Mangement, an Experiental Approach. Singapore: Mc Graw Hill Book Co.

7. Chandrasekara, W. S. 2019. "The Effect of Transformational Leadership Style on Employees Job Satisfaction and Job Performance: A Case of Apparel Manufacturing Industry in Sri Lanka." International Journal of Economics, Commerce and Management 8 (7): 385-393.

8. Daft, R. 2015. The Leadership Experience. 6th Eds. USA: Cengage Learning. 

company.

9. Elgelal, K. S. K., and N. Noermijati. 2015. "The Influences of Transformational Leaderships on Employees Performance (a Study of the Economics and Business Faculty Employee at University of Muhammadiyah Malang )." Asia-Pacific (Management and Business Application) 3 (1): 48-66.

10. Gibson, J. L., J. M. Ivancevich, H. Donnely Jr, and R. Konopaske. 2012. Organization: Behaviour, Structure, and Process. Fourteenth. Boston: Boston: McGraw-Hill,.

11. Gong, Y., J. C. Huang, and J. L. Farh. 2009. "Employee Learning Orientation, Transformational Leadership, and Employee Creativity: The Mediating Role of Employee Creative Self-Efficacy." Academy of Management Journal 52 (4): 765-778.

https://doi.org/10.5465/amj.2009.43670890.

12. Hase, C. A. 2007. "First-Line Leadership Development: Its Impact on Organizational Performance Aboard United States Navy Ships." Capella University. ProQuest Dissertations Publishing,.

13. Italiani, F. A. 2013. "Pengaruh Gaya Kepemimpinan Transformasional Dan Transaksional Terhadap Kinerja Pegawai Departemen SDM PT. Semen Gresik (Persero) Tbk." Jurnal Bisnis Dan Manajemen 6 (1): 11-18.

14. Jiang, C., L. Lu, and J. J. Lu. 2017. "Socioeconomic Factors Affecting the Job Satisfaction Levels of Self-Employed Container Truck Drivers: A Case Study from Shanghai Port." Maritime Policy \& Management 44 (5): 641-656.

15. Jung, B. M., and S. J. Kim. 2012. "Change of Shipping Industry Circumstances and Shipping Policy Directions of Developing and Developed Countries." The Asian Journal of Shipping and Logistics 28 (2): 135-160.

16. Kadarisman, M. 2017. "Kebijakan Keselamatan Dan Keamanan Maritim Dalam Menunjang Sistem Transportasi Laut." Jurnal Manajemen Transportasi \& Logistik 4 (2): 177-192. https://doi.org/10.25292/j.mtl.v4i2.121.

17. Kreitner, R., and A. Kinicki. 2011. Organizational Behavior. 9th Eds. New York: McGraw-Hill Irwin.

18. Lai, K. H.., C. W. Wong, Y. V. Lun, and T. C. E. Cheng. 2013. "Shipping Design for Compliance and the Performance
Contingencies for Shipping Firms." Transportation Research Part E: Logistics and Transportation Review 55: 74-83.

19. Latif, M. S., M. Ahmad, M. Qasim, M. Mushtaq, A. Ferdoos, and H. Naeem. 2013. "Impact of Employee's Job Satisfaction on Organizational Performance." European Journal of Business and Management 5 (5): 166-171.

20. Lun, Y. V., K. H. Lai, C. W. Wong, and T. C. E. Cheng. 2014. "Green Shipping Practices and Firm Performance. Maritime Policy \& Management." Maritime Policy \& Management 41 (2): 134-148.

21. Mancheno-Smoak, L., G. M. Endres, R. Polak, and Y. Athanasaw. 2009. "The Individual Cultural Values and Job Satisfaction of the Transformational Leader." Organization Development Journal 27 (3).

22. Mehrad, A., and B. Fallahi. 2014. "The Role of Leadership Styles on Staff' s Job Satisfaction in Public Organizations." Acta Universitaria 24 (5): 27-32.

23. Mehrad, Aida, and Bahareh Fallahi. 2014. "The Role of Leadership Styles on Staff 's Job Satisfaction in Public Organizations." Acta Universitaria 24 (5): 27-32. https://doi.org/10.15174/au.2014.597.

24. Miah, M. M. 2018. "The Impact of Employee Job Satisfaction toward Organizational Performance: A Study of Private Sector Employees in Kuching, East Malaysia." International Journal of Scientific and Research Publications 8 (12): 270-278.

25. Mujkić, A., D. Šehić, Z. Rahimić, and J. Jusić. 2014. "Transformational Leadership and Employee Satisfaction." Ekonomski Vjesnik: Review of Contemporary Entrepreneurship, Business, and Economic Issues 27 (2): 259-270.

26. Muslichah, Muslichah, and Sobikhul Asrori. 2018. "The Effect of Transformational Leadership Style on Job Satisfaction with Trust-In-Leader as Intervening Variable." Journal of Innovation in Business and $\begin{array}{llll}\text { Economics } & 2 & (02):\end{array}$ https://doi.org/10.22219/jibe.v2i02.6580.

27. Muterera, J., D. Hemsworth, A. Baregheh, and B. R. Garcia-Rivera. 2018. "The Leader-Follower Dyad: The Link between Leader and Follower Perceptions of Transformational Leadership and Its Impact on Job Satisfaction and Organizational 
Performance." International Public Management Journal 21 (1): 131-162.

28. Newstrom, J. W. 2015. Organizational Behavior. Human Behavior at Work. 14th Eds. New York: McGraw-Hill Education.

29. Noruzy, A., V. M. Dalfard, B. Azhdari, S. Nazari-Shirkouhi, and A. Rezazadeh. 2013.

"Relations between Transformational Leadership, Organizational Learning, Knowledge Management, Organizational Innovation, and Organizational Performance: An Empirical Investigation of Manufacturing Firms." The International Journal of Advanced Manufacturing Technology 64 (5-8): 1073-1085.

30. Noviyanti, Enny, Efrizal Syofyan, and Susi Evanita. 2019. "The Effect of Leadership, Work Motivation and Work Satisfaction on Performance of Employees of Education and Culture Department in Padang Pariaman" 97 (Piceeba): 685-95. https://doi.org/10.2991/piceeba-19.2019.74.

31. Pang, K., and C. S. Lu. 2018. "Organizational Motivation, Employee Job Satisfaction and Organizational Performance: An Empirical Study of Container Shipping Companies in Taiwan." Maritime Business Review. 3 (1): 36-52.

32. Pratama, G. 2016. "Effect of Transformational Leadership Towards Employee's Performance Through Satisfaction and Moderated by Culture." Jurnal Ekonomi Universitas Esa Unggul 7 (2): 77826.

33. Purnama, C. 2013. "Influence Analysis of Organizational Culture Organizational Commitment Job and Satisfaction Organizational Citizenship Behavior (OCB) toward Improved Organizational Performance." International Journal of Business, Humanities and Technology 3 (5): 86-100.

34. Riana, I. G., D. K. Sintaasih, and M. Suprapta. 2015. "Pengaruh Kepemimpinan Terhadap Kepuasan Kerja Dan Kinerja Karyawan (Studi Pada Wake Bali Art Market Kuta-Bali)." E-Jurnal Ekonomi Dan Bisnis Universitas Udayana 4: 44744.

35. Robbins, S.P., and T. A. Judge. 2018. Essentials of Organizational Behavior. 14th Eds. New Jersey: Pearson Education, Inc,.

36. Shahzad, F., R. A. Luqman, A. R. Khan, and L. Shabbir. 2012. "Impact of
Organizational Culture on Organizational Performance: An Overview." Interdisciplinary Journal of Contemporary Research in Business 3 (9): 975-985.

37. Shin, S. J., and J. Zhou. 2003. "Transformational Leadership, Conservation, and Creativity: Evidence from Korea." Academy of Management $\begin{array}{llll}\text { Journal } & 46 & \text { (6): } & \text { 703-714. }\end{array}$ https://doi.org/10.5465/30040662.

38. Suwestian, M. F., S. Ghalib, and S. Utomo. 2015. "Implementasi Kebijakan Sistem Manajemen Keselamatan Pelayaran (Studi Di PT. Maritim Barito Perkasa Banjarmasin)." Jurnal Bisnis Dan Pembangunan 3 (1): 1-5.

39. Thamrin, H. M. 2012. "The Influence of Transformational Leadership and Organizational Commitment on Job Satisfaction and Employee Performance." International Journal of Innovation, Management and Technology 3 (5): 566572.

https://doi.org/10.7763/IJIMT.2012.V3.299.

40. Tsai, C. L. 2014. "The Organizational Climate and Employees' Job Satisfaction in the Terminal Operation Context of Kaohsiung Port." The Asian Journal of Shipping and Logistics 30 (3).

41. Tschannen-Moran, M. 2003. "Fostering Organizational Citizenship in Schools: Transformational Leadership and Trust." In Journal of Educational Administration., 136.

42. Vasilcovschi, N., and S. Georgescu. 2012. "Transformational Leadership and The Economic Competitiveness in Shipping Industry Today." Analele Universitatii Maritime Constanta 13 (17): 307-10.

43. Yao, C., and P. Huang. 2018. "Effects of Leadership Style on Job Satisfaction and Intention to Stay in Shipping Industry." Journal of Coastal Research 83 (10083): 796-801.

How to cite this article: Ricardianto P, Setiawan WA, Veronica et.al. Employee job satisfaction and organizational performance on the national shipping company. International Journal of Research and Review. 2021; 8(9): 497-506. DOI: https://doi.org/10.52403/ijrr.20210963 